Jurnal Viabel Pertanian Vol. 13 No. 1 Mei 2019

p-ISSN: 1978-5259 e-ISSN: 2527-3345

Copyright@UNISBA Blitar, http://ejournal.unisbablitar.ac.id/index.php/viabel

Palupi Puspitorini \& Tri Kurniastuti 2019. Kajian Durasi Perendaman Auxin Natural Pada

Pertumbuhan Dan Hasil Bawang Merah (Allium Ascalonicum L) Journal Viabel Pertanian. (2019), 13(1)1-10

\title{
KAJIAN DURASI PERENDAMAN AUXIN NATURAL PADA PERTUMBUHAN DAN HASIL BAWANG MERAH (Allium ascalonicum L)
}

\author{
Palupi Puspitorini ${ }^{1)}$ dan Tri Kurniastuti ${ }^{1)}$ \\ ${ }^{1)}$ Dosen Program Studi Agroteknologi Fakultas Pertanian Universitas Islam Balitar \\ Email : Palupi.puspitirini@gmail.com
}

\begin{abstract}
The aims of this study is to determine the soaking time of the seeds with natural auxin which is appropriate for the growth and production of shallots (Allium ascalonicum L). The study was arranged in a randomized treatment group 7 treatment and repeated $4 x$. The treatment was soaking time of shallot seeds $(D)$. There are 28 field trial units. Treatment consisted of DO = without soaking, D1 = soaking 2 hours, D2 = soaking 4 hours, D3 = soaking 6 hours, D4 = soaking 8 hours, D5 = soaking 10 hours, D6 = soaking 12 hours. The variables observed were shoot length, shallot / plant weight, tuber diameter. The results of the study showed that the 3 variables observed showed the best results in D3 treatment (soaking for 6 minutes) in natural coconut water. The best treatment is D3, which is a tuber weight value of 41.01 grams per plant with a tuber diameter of $2.01 \mathrm{~cm}$.
\end{abstract}

Keywords: cow urine, natural auxin, shallots

\section{PENDAHULUAN}

Peningkatan produksi bawang merah perlu dilakukan di antaranya dengan meningkatkan hasil produksi bawang merah melalui percepatan pertumbuhan benihnya. Salah satunya adalah perendaman pada zat pengatur tumbuh dengan kandungan auxin dan sitokinin untuk pemacuan pertumbuhan benih bawang merah.. Didalam air kelapa terkandung ZPT endogen seperti sitokinin, auksin, giberelin. Fungsi auxin adalah dapat meningkatkan penggandaan sel sehingga dapat pertumbuhan tanaman meningkat. Sitokinin berfungsi meningkatkan perpanjangan sel tanaman, giberelin dapat memacu terbelahya sel dan dan pemanjangan sel atau keduanya.

Penelitian dengan perlakuan konsentrasi dan lama perendaman dalam air kelapa pada bibit bawang merah menunjukkan hasil bahwa lama perlakuan lama perendaman terbaik adalah L1 (2jam), yang secara nyata meningkatkan panjang bibit umur 7 MST yaitu $19,30 \mathrm{~cm}$; bobot basah umbi bawang merah 16,13 g per tanaman; bobot basah umbi $364,23 \mathrm{~g}$ per plot; dan bobot kering seberat $312,94 \mathrm{~g}$ per plot dibandingkan perendaman L2 (4 jam) dan L3 (6 jam ).(18). Sedangkan lama perendaman pada tanaman rosela terbaik didapatka pada perlakuan 8 jam (19).

Tanaman mengandung hormon endogen yaitu Giberilin, Sitokinin dan Auksin. Jaringan meristem merupakan jaringan yang paling banyak mengandung hormone endogen 
Jurnal Viabel Pertanian Vol. 13 No. 1 Mei 2019

p-ISSN: 1978-5259 e-ISSN: 2527-3345

Copyright@UNISBA Blitar , http://ejournal.unisbablitar.ac.id/index.php/viabel

Palupi Puspitorini \& Tri Kurniastuti 2019. Kajian Durasi Perendaman Auxin Natural Pada

Pertumbuhan Dan Hasil Bawang Merah (Allium Ascalonicum L) Journal Viabel Pertanian. (2019), 13(1)1-10

karena jaringan meristem merupakan jaringan aktif tumbuh. Hormone endogen mempengaruhi pertumbuhan vegetative dan genertif pada tanaman. (Anonim, 2009).

Apabila unsur hara yang diperlukan oleh tanaman sudah terpenuhi, maka proses fisiologis tanaman berjalan dengan baik. Luas daun yang besar meningkatkan laju fotosintesis tanaman Hasil fotosintesa akan mendukung kerja sel jaringan tanaman sehingga mempercepat pertumbuhan dan perkembangan contohnya daun, batang, akar. Pemberian zat pengatur tumbuh menjadi penting saat konsentrasi endogen berada di bawah jumlah optimal dan dibutuhkan pemberian sumber hormon dari luar untuk menghasilkan respon yang dikehendaki. Pada bibit bahwa pemberian zat pengatur tumbuh diduga meningkatkan kualitas bibit.

Terdapat tiga cara yang sering digunakan dalam aplikasi zat pengatur tumbuh yaitu Concentrated Solution Dip Method, Dilute Solution Soaking Method, dan Commercial Powder Preparation. Pada metode pencelupan cepat, dilakukan pencelupan cepat pada pangkal batang sekitar lima detik pada konsentrasi antara 500 ppm hingga 10000 ppm . Pada metode perendaman dilakukan dengan cara merendam pangkal batang dalam larutan selama 24 jam sebelum ditanam. Konsentrasi yang digunakan bervariasi mulai dari $20 \mathrm{ppm}$ hingga 200 ppm. Pada metode pasta, pangkal batang dioles hormon dengan konsentrasi 200 ppm hingga 1000 ppm.

Dari hasil penelitian bahwa air kelapa mengandung potasium (kalium) yaitu 17 persen, gula 1,7 sampai 2,6\%, protein 0,07 hingga 0,55 persen, natrium $(\mathrm{Na})$, kalsium $(\mathrm{Ca})$, magnesium $(\mathrm{Mg})$, ferum $(\mathrm{Fe})$, cuprum $(\mathrm{Cu})$, fosfor $(\mathrm{P})$ dan sulfur $(\mathrm{S})$, vitamin yaitu asam sitrat, asam nikotinaat, asam pantotenal, asam folat, niacin, riboflavin, dan thiamin, auksin dan sitokinin (8)., hormon sitokinin 5,8 mg/l, auksin 0,07 mg/l dan giberelin sedikit sekali serta senyawa lain yang dapat menstimulasi perkecambahan dan pertumbuhan. Diduga peningkatan pertumbuhan karena auksin berperan pada pertumbuhan tersebut. Saidah (2005) menyampaikan bahwa auksin diproduksi dalam jaringan meristematik yang aktif. Kelapa muda adalah jaringan meristem, yang menghasilkan hormon pertumbuhan sekali. Lebih lanjut Hendaryono dan Wijayati, 1994 memberi pernyataan bahwa air kelapa adalah endosperm cair dengan kandungan difenil urea yang dapat memacu pembelahan sel.

Giberellin juga sangat berpengaruh pada sifat genetik, pembungaan, penyinaran, patohenocarpy, mobilisasi karbohidrat selama perkecambahan (germination) dan aspek fisiologi lainnya. Mempunyai peran mendukung: perpanjangan sel (celelongtion), aktivitas kambium dan mendukung pembentukan RNA baru sertasintesa protein.

Sitokinin adalah ZPT yang mempunyai fungsi dalam proses pembelahan sel (cel division), yang dibutuhkan untuk pembelahan sel dan morfogenesis. Karena kinin terbukti tidak ditranslokasikan ke jaringan-jaringan ini, diperkirakan disitulah tempat sintesisnya.

Fungsi sitokinin adalah memacu pembelahan sel meristematik, merangsang diferensiasi sel, mendorong pertumbuhan tunas samping, dominasi pucuk dan perluasan daun, menunda penuaan daun, merangsang terbentuknya tunas, memecah masa dormansi biji (breaking dormancy) serta merangsang pertumbuhan embrio. Macam sitokinin adalah sitokinin alami (kinetin, zeatin) yang dihasilkan oleh jaringan meristematik terutama pada akar, embrio dan buah. Sitokinin jugadihasilkan di akar selanjutnya diangkut oleh xilem menuju sel target pada batang. Peningkatan konsentrasi sitokinin diduga menyebabkan pembentukan cabang lebih banyak. Auksin dan sitokinin memacu pembelahan sel dan mempengaruhi differensiasi. Pengaruh sitokinin pada pertumbuhan sel di dalam tissue 
Jurnal Viabel Pertanian Vol. 13 No. 1 Mei 2019

p-ISSN: 1978-5259 e-ISSN: 2527-3345

Copyright@UNISBA Blitar , http://ejournal.unisbablitar.ac.id/index.php/viabel

Palupi Puspitorini \& Tri Kurniastuti 2019. Kajian Durasi Perendaman Auxin Natural Pada

Pertumbuhan Dan Hasil Bawang Merah (Allium Ascalonicum L) Journal Viabel Pertanian. (2019), $13(1) 1-10$

culture. Ketika satu potongan batang dikulturkan tanpa memakai sitokinin, maka sel tersebut tumbuh menjadi besar tetapi tidak membelah. Sitokinin secara mandiri tidak mempunyai pengaruh, tetapi apabila diberikan bersama-sama dengan auksin maka sel tersebut dapat membelah.

\subsection{Lama Perendaman}

Pada perbanyakan secara generatif seringkali ditemukan masalah lama waktu benih untuk berkecambah yang disebabkan faktor permeabilitas kulit biji dan ketersediaan air di sekitar biji. Jika faktor tersebut tidak diatasi maka biji akan mengundurkan waktu berkecambah (dormansi). Fungsi hormon akan menstimulir sintesis enzim ribonuklease, amilase dan protease pada biji.

Lama perendaman benih aka berpengaruh pada proses perkecambahan. Semakin lama waktu untuk perendaman semakin baik persentase jumlah benih yang berkecambah. Air berfungsi mengimbibisi dinding sel dalam biji dan menentukan turgiditas sel sebelum membelah. Sedangkan gas $\mathrm{O}_{2}$ juga akan membantu berjalannya proses perkecambahan yang masuk melalui sel secara difusi. Dengan terjadinya proses pernafasan maka benih akan cepat berkecambah. Biji yang tidak direndam, dinding selnya tidak permeable untuk gas. Pada biji yang direndam dengan air dapat membentuk alat transport makanan. Kekurangan air menyebabkan pembentukan sitoplasma baru berlangsung lambat. Air berpengaruh pada kecepatan reaksi biokimia dalam sel yang memacu kinerja enzim. Penelitian tentang konsentrasi air kelapa yang dikombinasikan dengan lama perendaman tidak memberikan interaksi nyata pada bobot umbi dan semua peubah pengamatan. Sedangkan hasil penelitian yang lain mengenai lama perendaman air kelapa pada rosela bahwa perlakuan terbak adalah perendaman benih 8 jam sebelum ditanam.

Tujuan penelitian adalah menentukan lama perendaman bibit dengan auxin alami yang tepat pada pertumbuhan dan hasil tanaman bawang merah (Allium ascalonicum L).

\section{METODOLOGI PENELITIAN}

\section{Waktu Dan Tempat Penelitian}

Penelitian dilaksanakan pada bulan Januari hingga Maret 2019 di Desa Tlogo Kecamatan Kanigoro Kabupaten Blitar pada ketinggian tempat 150 meter dari permukaan laut.

\section{Alat Dan Bahan}

Alat yang di gunakan adalah penggaris $50 \mathrm{~cm}$, timbangan kapasitas $5 \mathrm{~kg}$, jangka sorong.. Bahan terdiri dari bawang merah varietas Thailand, herbisida, air kelapa muda dan pupuk NPK.

\section{Pelaksanaan Percobaan}

Benih bawang merah yang akan dipakai adalah varietas Thailand. Pengolahan lahan menggunakan cangkul dengan membersihkan sisa-sisa gulma . Pembuatan bedengan dan pemulsaan dilakukan sebelum dilakukan penanaman. Pengaplikasian ZPT Air kelapa di 
Jurnal Viabel Pertanian Vol. 13 No. 1 Mei 2019

p-ISSN: 1978-5259 e-ISSN: 2527-3345

Copyright@UNISBA Blitar, http://ejournal.unisbablitar.ac.id/index.php/viabel

Palupi Puspitorini \& Tri Kurniastuti 2019. Kajian Durasi Perendaman Auxin Natural Pada

Pertumbuhan Dan Hasil Bawang Merah (Allium Ascalonicum L) Journal Viabel Pertanian. (2019), 13(1)1-10

laksanakan ketika benih akan di tanam. Dilakukan perendaman benih bawang merah dengan ZPT Air kelapa muda dengan konsentrasi $100 \%$ dan 5 level perlakuan lama perendaman, yaitu 2,3,4,5,6 jam sebelum tanam. Penanaman yang dilakukan pada siang atau sore hari. Jarak tanam 15x15 dan benih di tanam pada guludan. Sampel 3 tanaman dalam setiap plot percobaan. Pemeliharaan tanaman bawang merah meliputi : penyiraman, penyulaman, penyiangan gulma dan pengendalian gulma. Peubah pengamatan adalah: Panjang tunas diukur dari pangkal batang diatas tanah sampai titik tumbuh tertinggi pada $10 \mathrm{hst}, 20 \mathrm{hst}, 30$ hst, 40 hst 50 hst, 60 hst, minimaltunas yang diukur dengan tinggi $5 \mathrm{~cm}$. Pengamatan panen dilaksanakan pada umur 49 hst dengan cara menimbang umbi basah dan telah dikeringanginkan selama 7 hari lalu ditimbang setelah dibuang daun keringnya. . Pengamatan ini dilakukan dengan timbangan digital kapasitas $5 \mathrm{~kg}$. Rata-rata diameter umbi diukur pada saat panen menggunakan alat jangka sorong

\section{Rancangan Percobaan}

Penelitian disusun dalam Rancangan Acak Kelompok 7 perlakuan dan diulang 4x. Perlakuan adalah lama dipping bibit bawang merah dalam urine natural (D). Terdapat 28 unit percobaan lapang. Perlakuan terdiri dari D0 $=$ tanpa direndam , D1 = rendam 2 menit, D2 = rendam 4 menit, D3 = rendam 6 menit, $\mathrm{D} 4=$ rendam 8 menit, $\mathrm{D} 5=$ rendam 10 menit, D6 = rendam 12 menit.

\section{Analisis Data}

Analisis data rata-rata dihitung dengan analisis ragam pada level 5\%. Apabila ada perbedaan yang significan akan dilanjutkan dengan uji Beda Nyata Jujur (BNJ) pada taraf 5 $\%$.

\section{. HASIL DAN PEMBAHASAN}

\section{Panjang tunas $(\mathbf{c m})$}

Hasil analisis varian pada perlakuan perendaman benih bawang merah dalam beberapa lama perendaman (D) didapatkan bahwa Panjang tunas (cm) pada umur 7, 14, 21, 28 HST berbeda nyata antara perlakuan satu dengan perlakuan lainnya. Analisis BNJ 5\% antar perlakuan disajikan pada Table 1 berikut, 
Jurnal Viabel Pertanian Vol. 13 No. 1 Mei 2019

p-ISSN: 1978-5259 e-ISSN: 2527-3345

Copyright@UNISBA Blitar, http://ejournal.unisbablitar.ac.id/index.php/viabel

Palupi Puspitorini \& Tri Kurniastuti 2019. Kajian Durasi Perendaman Auxin Natural Pada

Pertumbuhan Dan Hasil Bawang Merah (Allium Ascalonicum L) Journal Viabel Pertanian. (2019), 13(1)1-10

Tabel 1. Rata-rata Panjang Tunas Pada Perlakuan Lama Perendaman Air Kelapa Pada Beberapa Umur

\begin{tabular}{ccccccccccccc}
\hline \multicolumn{1}{c}{$\begin{array}{c}\text { Perlakuan } \\
\text { (menit) }\end{array}$} & & 7 & $\mathrm{a}$ & 21 & & 35 & & 49 & & 63 \\
\hline D0 & 0 & 4,16 & $\mathrm{a}$ & 9,02 & $\mathrm{~A}$ & 19,70 & $\mathrm{a}$ & 28,80 & $\mathrm{ab}$ & 33,17 & $\mathrm{~b}$ \\
$\mathrm{D} 1$ & 2 & 4,47 & $\mathrm{a}$ & 11,60 & $\mathrm{~B}$ & 22,15 & $\mathrm{ab}$ & 27,76 & $\mathrm{a}$ & 33,71 & $\mathrm{~b}$ \\
$\mathrm{D} 2$ & 4 & 4,82 & $\mathrm{a}$ & 11,23 & $\mathrm{~B}$ & 23,91 & $\mathrm{~b}$ & 28,67 & $\mathrm{a}$ & 32,08 & $\mathrm{ab}$ \\
$\mathrm{D} 3$ & 6 & 5,40 & $\mathrm{a}$ & 8,33 & $\mathrm{~A}$ & 23,88 & $\mathrm{~b}$ & 30,59 & $\mathrm{~b}$ & 36,14 & $\mathrm{c}$ \\
$\mathrm{D} 4$ & 8 & 5,36 & $\mathrm{a}$ & 8,47 & $\mathrm{~A}$ & 22,03 & $\mathrm{ab}$ & 27,56 & $\mathrm{a}$ & 31,71 & $\mathrm{ab}$ \\
$\mathrm{D} 5$ & 1 & 4,90 & $\mathrm{a}$ & 8,86 & $\mathrm{~A}$ & 20,38 & $\mathrm{a}$ & 27,16 & $\mathrm{a}$ & 30,71 & $\mathrm{a}$ \\
& 0 & & & & & & & & & & \\
D6 & 1 & 5,70 & $\mathrm{a}$ & 7,83 & $\mathrm{~A}$ & 21,72 & $\mathrm{ab}$ & 27,13 & $\mathrm{a}$ & 31,76 & $\mathrm{a}$ \\
Sig & 2 & & & & & & & & & & \\
$(\%)$ & & 0,33 & & 0,43 & & 1,24 & & 0,39 & & 0,62 & \\
\hline
\end{tabular}

Dari data pada Tabel 1 memperlihatkan bahwa panjang tunas terbaik didapatkan pada perlakuan D3 yaitu perlakuan perendaman bibit bawang merah pada larutan air kelapa selama 6 menit pada umur pengamatan 35, 49, 63 HST. Perlakuan terjelek adalah D0 yaitu tanpa perendaman yang tidak berbeda dengan perlakuan perendaman D1 dan D2 peredaman selama 2 dan 4 menit.

\section{Bobot Umbi Per tanaman (gram)}

Hasil analisis varian pada perlakuan perendaman benih bawang merah dalam beberapa lama waktu perendaman (D) air kelapa didapatkan bahwa bobot umbi per tanaman berbeda nyata antara perlakuan satu dengan perlakuan lainnya. Analisis BNJ antar perlakuan disajikan pada Table 2 berikut,

Tabel 2. Rata-rata Bobot Umbi Pada Perlakuan Lama Perendaman Air Kelapa Saat Panen (49 HST)

\begin{tabular}{cccc}
\hline \multicolumn{2}{c}{ Perlakuan (menit) } & Bobot Umbi (gram per tanaman) \\
\hline D0 & 0 & 30,47 & $\mathrm{a}$ \\
D1 & 2 & 31,42 & $\mathrm{a}$ \\
D2 & 4 & 33,47 & $\mathrm{~b}$ \\
D3 & 6 & 41,01 & $\mathrm{~d}$ \\
D4 & 8 & 36,81 & $\mathrm{c}$ \\
D5 & 10 & 35,81 & $\mathrm{c}$ \\
D6 & 12 & 36,04 & $\mathrm{c}$ \\
\hline Sig $(\%)$ & & 0,23 & \\
\hline
\end{tabular}


Jurnal Viabel Pertanian Vol. 13 No. 1 Mei 2019

p-ISSN: 1978-5259 e-ISSN: 2527-3345

Copyright@UNISBA Blitar , http://ejournal.unisbablitar.ac.id/index.php/viabel

Palupi Puspitorini \& Tri Kurniastuti 2019. Kajian Durasi Perendaman Auxin Natural Pada

Pertumbuhan Dan Hasil Bawang Merah (Allium Ascalonicum L) Journal Viabel Pertanian. (2019), 13(1)1-10

Bobot basah umbi per tanaman terbaik didapatkan pada perlakuan D3 yaitu perlakuan perendaman dalam urine natural selama 6 menit dengan nilai bobot umbi per tanaman 41,01 gram per tanaman. Hasil tersebut berbeda dengan perlakuan yang lainnya yaitu perendaman selama 2,4,,8,10 dan 12 menit sebelum tanam. Perlakuan terjelek adalah perlakuan D0 yaitu tanpa perendaman yang tidak berbeda dengan perlakuan D1 kemudian disusul lebih baik perlakuan D4, D5 dan D6 dengan kisaran antara 36,04 - 36,81 gram per tanaman.

\section{Diameter Umbi}

Hasil analisis varian pada perlakuan perendaman benih bawang merah dalam beberapa lama perendaman (D) didapatkan bahwa Bobot umbi per tanaman berbeda nyata antara perlakuan satu dengan perlakuan lainnya. Analisis BNJ antar perlakuan disajikan pada Table 3 berikut

Tabel 3. Rata-rata Diameter Umbi Pada Perlakuan Lama Perendaman Air Kelapa Natural Saat Panen (49 HST)

\begin{tabular}{cccc}
\hline \multicolumn{2}{l}{ Perlakuan (menit) } & Diameter umbi $(\mathrm{cm})$ & \\
\hline D0 & 0 & 1,87 & $\mathrm{a}$ \\
D1 & 2 & 1,92 & $\mathrm{~b}$ \\
D2 & 4 & 2,06 & $\mathrm{c}$ \\
D3 & 6 & 2,10 & $\mathrm{~d}$ \\
D4 & 8 & 1,87 & $\mathrm{a}$ \\
D5 & 10 & 1,90 & $\mathrm{bc}$ \\
D6 & 12 & 1,91 & $\mathrm{bc}$ \\
\hline Sig $(\%)$ & & & 0,40 \\
\hline
\end{tabular}

Diameter umbi per tanaman terbaik didapatkan pada perlakuan D3 yaitu perlakuan perendaman dalam urine natural selama 6 menit dibandingkan dengan perlakuan lainnya dengan nilai diameter umbi per tanaman $2,10 \mathrm{~cm}$. Hasil itu berbeda dengan perlakuan perendaman D1, D2, D4, D5, dan D6 yaitu perendaman selama 0, 2,4,8,10 dan 12 menit sebelum tanam.

Menurut Guritno B dan SM Sitompul (1995) bahwa pertumbuhan diketahui dengan mengukur pertambahan panjang suatu tanaman. Bahwa penambahan ukuran tanaman ini memperlihatkan pertumbuhan serta perkembangan tanaman yang semakin meningkat. Semakin besar penambahan ukuran suatu tanaman maka akan menggambarkan bahwa tanaman tumbuh lebih baik dibandingkan tanaman yang lainnya. Dari hasil penelitian pengaruh lama perendaman benih bawang merah pada larutan air kelapa natural didapatkan bahwa panjang tunas yang terbaik adalah perlakuan D3 yaitu perendaman benih bawang merah selama 6 menit sebelum dilakuan penanaman. 
Jurnal Viabel Pertanian Vol. 13 No. 1 Mei 2019

p-ISSN: 1978-5259 e-ISSN: 2527-3345

Copyright@UNISBA Blitar , http://ejournal.unisbablitar.ac.id/index.php/viabel

Palupi Puspitorini \& Tri Kurniastuti 2019. Kajian Durasi Perendaman Auxin Natural Pada

Pertumbuhan Dan Hasil Bawang Merah (Allium Ascalonicum L) Journal Viabel Pertanian. (2019), 13(1)1-10

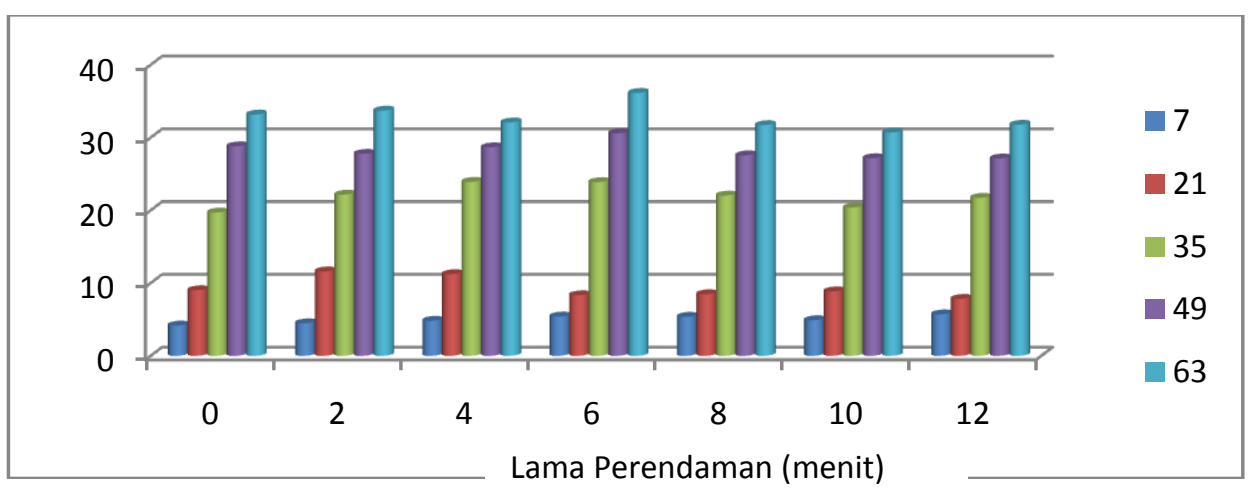

Gambar 1. Panjang tunas bawang merah

Gambar 1 diatas memperlihatkan bahwa perlakuan lama perendaman terbaik adalah D3 yaitu perlakuan perendaman selama 6 menit. Hal ini dimungkinkan disebabkan karena lama perendaman benih bawang merah tidak bagus apabila terlalu lama, 6 menit merupakan durasi optimal dlam perendama benih. Tunas merupakan bagian embrionik yang sangat sensitif terhadap pengaruh luar yang ekstrim dan tidak bisa ditoleransi oleh tanaman dan mengakibatkan cekaman bagi pertumbuhannya. Jika terlalu lama perendaman dimungkinkan melemahkan embrio untuk tumbuh dengan baik

Hasil analisis pada variabel bobot umbi didapatkan bahwa perlakuan terbaik adalah D3 (perendaman selama 6 menit) yang menghasilkan bobot umbi 41,01 gram per tanaman. Bobot segar adalah indikator pertumbuhan yang berkaitan dengan hasil proses metabolisme tanaman yang secara fisiologis bahan utamanya adalah air dan karbohidrat. Peningkatan bobot umbi menggambarkan meningkatnya proses metabolisme fotosintesis pada tubuh tanaman yang ditandai oleh pembentukan organ-organ yang pada bawang merah adalah pada pembentukan umbinya. Hasil proses fotosintesis ini akan digunakan untuk proses respirasi yang menghasilkan O2 dan energi. Sesuai dengan pendapat Dwijoseputro (1982) yang mengatakan bahwa bobot suatu tanaman dipengaruhi oleh hasil fotosintesis yang terakumulasi pada organ tempat menyimpan cadangan makanan pada suatu tanaman. 
Jurnal Viabel Pertanian Vol. 13 No. 1 Mei 2019

p-ISSN: 1978-5259 e-ISSN: 2527-3345

Copyright@UNISBA Blitar , http://ejournal.unisbablitar.ac.id/index.php/viabel

Palupi Puspitorini \& Tri Kurniastuti 2019. Kajian Durasi Perendaman Auxin Natural Pada

Pertumbuhan Dan Hasil Bawang Merah (Allium Ascalonicum L) Journal Viabel Pertanian. (2019), $13(1) 1-10$

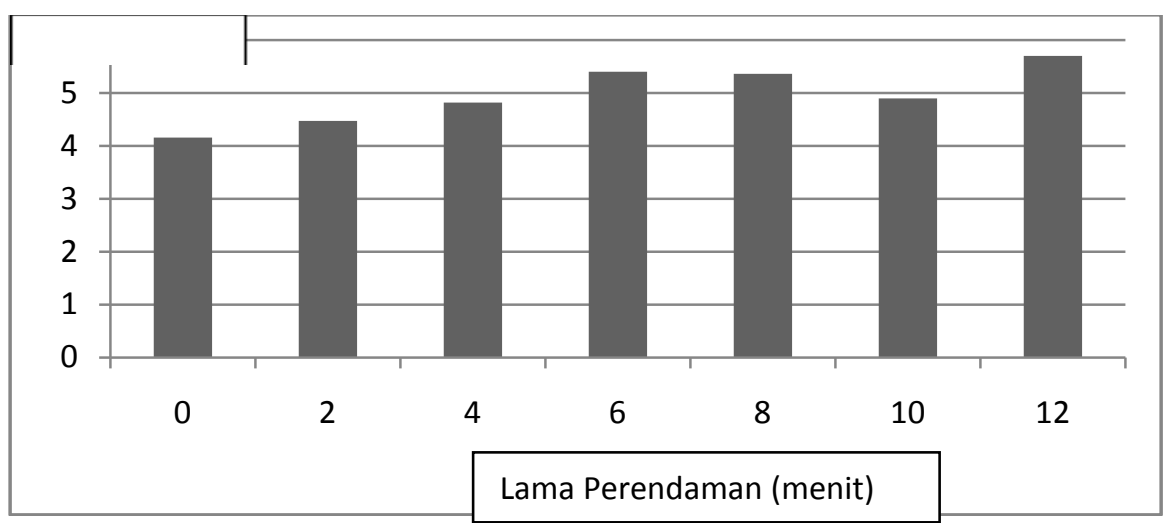

Gambar 2. Bobot Umbi bawang merah (saat panen) pada perlakuan lama perendaman benih bawang merah

Pada gambar 2 dapat dilihat bahwa perlakuan terbaik yaitu perlakun D3 (perendaman 6 menit) yang lebih baik dibandingkan dengan perlakuan lainnya.

Diameter umbi terbaik adalah pada perlakuan D3 ( perendaman selama 6 menit) dengan nilai $2,10 \mathrm{~cm}$.

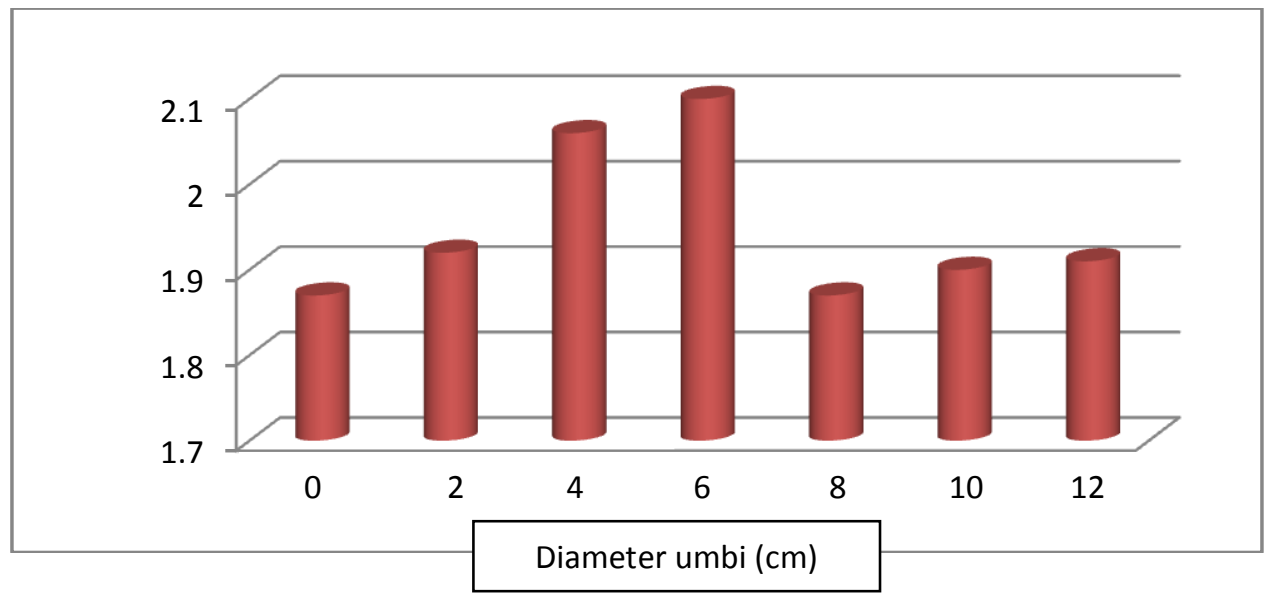

Gambar 3. Diameter umbi bawang merah pada perlakuan lama perendaman

Perlakuan D3 tersebut menghasilkan diameter umbi yang terbaik disebabkan karena muncul tunas untuk perlakuan D3 lebih awal. Sehingga pertumbuhan tanaman ini berlangsung paling cepat dibanding treatment lainnya. Keadaan ini juga dibuktikan dengan data panjang tunas dan bobot umbi bawang merah bahwa yang terbaik adalah perlakuan D3 
Jurnal Viabel Pertanian Vol. 13 No. 1 Mei 2019

p-ISSN: 1978-5259 e-ISSN: 2527-3345

Copyright@UNISBA Blitar , http://ejournal.unisbablitar.ac.id/index.php/viabel

Palupi Puspitorini \& Tri Kurniastuti 2019. Kajian Durasi Perendaman Auxin Natural Pada

Pertumbuhan Dan Hasil Bawang Merah (Allium Ascalonicum L) Journal Viabel Pertanian. (2019), $13(1) 1-10$

\section{Kesimpulan}

\section{KESIMPULAN DAN SARAN}

Dari penelitian kajian durasi perendaman auxin natural (air kelapa) pada pertumbuhan dan hasil bawang merah (Allium ascalonicum L) disimpulkan bahwa terdapat pengaruh nyata perlakuan lama perendaman pada variabel panjang tunas $(\mathrm{cm})$, bobot umbi (gram/tanaman) dan diameter umbi $(\mathrm{cm})$ antar perlakuan. Perlakuan terbaik didapatkan pada perlakuan D3 yaitu perendaman selama 6 menit dengan nilai bobot umbi 41,01 gram per tanaman dan diameter umbi $2,10 \mathrm{~cm}$.

\section{Saran}

Bahan auxin natural sebaiknya dianalisis terlebih dahulu $\mathrm{C} / \mathrm{N}$ ratio dan kandungan ammonia sebelum digunakan sebagai larutan perendaman benih bawang merah

\section{DAFTAR PUSTAKA}

Abidin, Z. 1987. Dasar-DasarPengetahuan Tentang ZPT . Bandung: Angkasa

Anwaruddin, M. J., N. L. P. Indrayani, S. Hardianti, dan E. Mansyah. 1996. Pengaruh konsentrasi asam giberelic dan lama perendaman terhadap perkecambahan dan pertumbuhan biji manggis. Jurnal Hortikultura 6: 1- 5.

Arnita, R. 2008. Pengaruh Sitokinin dan Pupuk Organik Terhadap Pertumbuhan dan Hasil Pule Pandak (Rauvolfia serpentina (L.) Benth.Ex Kurz). [Skripsi]. Fakultas Pertanian. Universitas Sebelas Maret. Surakarta. 57 hal

Dewi, I. R. 2008. Peranan dan Fungsi Fitohormon bagi Pertumbuhan Tanaman. Bandung: Fakultas Pertanian Universitas Padjadjaran.

Franklin, F. G. 1991. Fisiologi Tanaman Budidaya. Terjemahan Sri Andani. Yogyakarta: Universitas Islam Indonesia (UII Press).

Hartmann HT, Kester DE, Davis-Jr FT. 1990. Plant Propagational: Principles and Practices. New Jersey: Prentice-Hall International. Diakses, 10 Agustus 2018.

Haryanto, Eko, Tina Suhartini, Estu Rahayu, dan Hendro Sunarjono. 1995. Sawi dan Selada. Penebar Swadaya. Jakarta.

Ilmi Auliawati ,2013. Pengaruh Konsentrasi dan Lama Perendaman Dalam Air Kelapa Terhadap Vabilitas Benih Rosela Merah (Hibiscus sabdariffa var. sabdariffa). Skipsi Jurusan Biologi Fak Scientec UIN Malang.

Intan, R. D. A. 2008. Peran dan Fungsi Fitohormon Bagi Pertumbuhan Tanaman. Fakultas Pertanian. Universitasb Pajajaran. 43 hal.

Kharimah A, S Purwanti, dan R Rogomulyo. 2003. Kajian Perendaman Rimpang Temulawak dalam Air Kelapa dan Air Kelapa untuk Mempercepat Pertunasan. Jurnal Vegetalika 2(2):1-6. 
Jurnal Viabel Pertanian Vol. 13 No. 1 Mei 2019

p-ISSN: 1978-5259 e-ISSN: 2527-3345

Copyright@UNISBA Blitar, http://ejournal.unisbablitar.ac.id/index.php/viabel

Palupi Puspitorini \& Tri Kurniastuti 2019. Kajian Durasi Perendaman Auxin Natural Pada

Pertumbuhan Dan Hasil Bawang Merah (Allium Ascalonicum L) Journal Viabel Pertanian. (2019), $13(1) 1-10$

Kusuma, Mita. 2013. Fisiologi Tumbuhan - Pengaruh Lama Perendaman Biji. Makalah. Diakses tanggal 21 Agustus 2018.

Lukitariati, S., L. P. Indriyani., Susilo dan M. J. Anwaruddiansyah. 1996. Pengaruh konsentrasi indo butirat terhadap pertumbuhan manggis. Jurnal Hortikultura, Volume 6 (3): 220-226.

Mahadi, I. 2011. Pematahan Dormansi Biji Kenerak (Goniothalamus umbrosusu) dengan hormon 2,4-D dan BAP Secara Mikropropagasi. Sagu. Maret 2011. Vol.10 No.1:2023.

Nana S. dan S.Zochrotus. 2014. Pertumbuhan Tanaman Bawang Merah (Allium cepa L.) dan Penyiraman Air Kelapa (Cocos nucifera L.) Sebagai Sumber Belajar Biologi SMA Kelas XII . FMIPA.Universitas Ahmad Dahlan.Yogyakarta

Puspitasari , M. (2009). Pengaruh Lama Perendaman Dalam Air Kelapa dan Dosis Pupuk Kandang Sapi Terhadap Pertumbuhan Setek Nilam (Pogostemon cablin, Benth). Skripsi. Fak. Pertanian UNS

Simangunsong NL, , Ratna Rosanty Lahay, Asil Barus . 2017. Respon Pertumbuhan dan Haisl Bawang Merah (Allium ascalonicum L.) pada Konsentrasi Air Kelapa dan Lama Perendaman Umbi . Jurnal Agroekoteknologi FP USU E-ISSN No. 23376597 Vol.5.No.1, Januari 2017 (3): 17- 26

Untari, R., dan Dwi M.P. 2006. Pengaruh Bahan Organik dan NAA terhadap Pertumbuhan Anggrek Hitam (Coelogyne pandurata Lindl.) dalam Kultur in Vitro Bogor : Fakultas Kehutanan, Institut Pertanian Bogor. 